\title{
Malaysian medical tourism communication in shaping Indonesian public opinion
}

\author{
Trie Damayanti ${ }^{1}$, Susanne Dida ${ }^{2}$, Dadang Rahmat Hidayat ${ }^{3}$, Sung Kyum $\mathrm{Cho}^{4}$ \\ 1,2,3 Universitas Padjadjaran, Bandung, Indonesia \\ ${ }^{4}$ Chungnam National University, Daejeon, South Korea
}

\begin{abstract}
Malaysia is developing medical tourism as a tourism industry aimed at foreign tourists. For this tourism industry, Malaysia makes Indonesia as one of the tourist targets that are expected to bring foreign exchange for the country. Data shows that Indonesians are the largest contributor of tourists visiting Malaysia for treatment. This shows the trust of Indonesian citizens in the health services of the neighboring country. The concept of tourism communication mentions that to achieve the success of medical tourism at least several things are needed that can be fulfilled, namely: competitive prices, available human resources for medical services, the existence of research and development of medical capabilities, infrastructure development, state institutions that support medical tourism, a supportive market economy, the ability to bring together present-day medical technology with traditional, and tourist attractions. Things that are built through tourism communication itself are expected to produce a public opinion about tourist destinations, where this public opinion is the first step in the formation of a country's brand. This study uses a survey method, which involves about 96 respondents who are on the islands of Sumatra and Java. Use descriptive analysis techniques to explore results. The results obtained by not all components in tourism communication for medical tourism are seen as influencing Indonesian opinion on Malaysian medical tourism. The strangest thing that comes to the view of the Indonesian people is Malaysia's credibility on health services, the credibility of doctors, the equipment used, the ability to convey information, adequate infrastructure, and the beauty of tourist destinations. Most opinions state that Malaysia can show as a country that successfully develops tourist confidence in the health services offered. The implication of this research is that the opinion of foreign nationals in a country greatly affects the image of that country in the international world.
\end{abstract}

Keywords: Tourism communication; medical; tourism; opinions; Indonesian society

\section{Komunikasi pariwisata medis Malaysia dalam membentuk opini masyarakat Indonesia}

\begin{abstract}
ABSTRAK
Malaysia mengembangkan wisata medis sebagai industri pariwisata yang ditujukan untuk wisatawan asing. Untuk industri wisata ini Malaysia menjadikan Indonesia sebagai salah satu sasaran wisatawan yang diharapkan bisa mendatangkan devisa bagi negaranya. Data menunjukkan bahwa warga Indonesia menjadi penyumbang terbesar wisatawan yang mengunjungi Malaysia untuk melakukan pengobatan. Hal ini menunjukkan besarnya keyakinan warga Indonesia pada layanan kesehatan negara jiran tersebut. Konsep komunikasi pariwisata menyebutkan bahwa untuk mencapai keberhasilan sebuah wisata medis setidak-tidaknya diperlukan beberapa hal yang bisa dipenuhi, yaitu: harga yang kompetitif, tersedia sumber daya manusia untuk layanan medis, adanya penelitian dan pengembangan kemampuan medis, pengembangan infrastruktur, lembaga negara yang mendukung wisata medis, ekonomi pasar yang mendukung, kemampuan mempertemukan teknologi kedokteran masa kini dengan tradisional, dan daya tarik wisata. Hal yang dibangun melalui komunikasi pariwisata itu sendiri diharapkan dapat menghasilkan sebuah opini publik tentang destinasi wisata, dimana opini publik ini sebagai Langkah awal terbentuknya brand sebuah negara. Penelitian ini menggunakan metode survey, yang melibatkan sekitar 96 orang responden yang berada di Pulau Sumatera dan Jawa. Menggunakan teknik analisis deskriptif untuk mengeksplorasi hasil. Hasil yang diperoleh tidak semua komponen dalam komunikasi pariwisata untuk wisata medis dipandang mempengaruhi opini Masyarakat Indonesia pada Wisata Medis Malaysia. Hal yang peling mengemuka pada pandangan Masyarakat Indonesia adalah, kredibilitas Malaysia pada Tayanan kesehatan, kredibilitas dokter, peralatan yang digunakan, kemampuan menyampaikan informasi, infrastruktur yang memadai, dan keindahan tujuan wisata. Sebagian besar pendapat menyatakan bahwa Malaysia mampu menunjukkan sebagai negara yang berhasil mengembangkan kepercayaan wisatawan pada layanan kesehatan yang ditawarkan. Implikasi penelitian ini menunjukkan bahwa opini warga negara asing pada sebuah negara sangat mempengaruhi image negara tersebut di dunia internasional.
\end{abstract}

Kata-Kata kunci: Komunikasi pariwisata; wisata; medis; opini; masyarakat Indonesia

Korespondensi: Dr. Trie Damayanti, S.Sos., M.Si. Universitas Padjadjaran J1. Raya Bandung-Sumedang KM 21, Jawa Barat, 45363, Email: trie.damayanti@unpad.ac.id 


\section{INTRODUCTION}

Medical tourism is one of the tourism activities developed by Malaysia since the late 1990s. Malaysia began promoting this medical tourism after the monetary crisis that hit southeast Asian countries in 1997, which led to the decline of the tourism industry in all fields. Nevertheless, Malaysia sees an opportunity for many foreign tourists, especially Indonesia, to come to Penang for treatment. Since then, in 1998, Malaysia began promoting health tourism to penetrate the tourism and health sectors. To develop health tourism as an industry, Malaysia is working with the private sector to cooperate with the government to target tourists mainly around Asia and other countries in other parts of the world (Ormond et al., 2015). Malaysia's first thing in developing the industry was in January 1998; the Malaysian Government established the National Committee for the Promotion of Medical and Health Tourism to form the institutions necessary to provide policy support in growing the industry, especially the medical tourism industry. The task carried out by the agency is to identify target countries suitable for health tourism targets, propose appropriate tax incentives, budgeting costs, packaging messages, and determine the accreditation that must be achieved, as well as guidelines in promoting health tourism. Since the institution was established, the public and private sectors have cooperated actively and together to promote Malaysia as a medical tourism destination and encourage also diversifying its medical tourism industry. To date, Malaysia has promoted its medical tourism through tourism campaigns for up to $80 \%$ of its overall tourism campaigns (Azmi \& Chandran, 2018). Genç \& Genç Revealed that the need for innovation for the tourism industry is because this industry is the most competitive sector (Yasir, 2021).

The number of foreign tourists visiting Malaysia from 2012 to 2014 increased from $25,032,708$ to $27,437,315$. With an average of one to two million foreign visitors per month from 2012 to 2014, there was substantive growth, and the most significant growth was seen in 2014, although data compiled by the Tourism Board of Malaysia showed a decline in tourist arrivals in 2014-2015 to 25,721,251. Based on data from the Tourism Board of
Malaysia, approximately 70 million tourists, or $34 \%$ of all tourists, were patients seeking medical treatment in Malaysia in 2015. (Tourism Malaysia, 2020) Of these Indonesians occupy the second place in the most tourists visiting Malaysia, as many as 2 million Indonesian tourists each year visit Malaysia, although the results of Hoftsede research (1996) revealed that Indonesia as a collectivistic society usually expected to take care of oneself and one's immediate family (Mulyana et al., 2021)

Data from the Malaysia Healthcare Travel Council (MHTC), a coordinating body developed by Malaysia's Ministry of Health, in 2015 about 500,000 Indonesians were treated in the neighboring country, and of the 500,000 it mainly came from Sumatra, and the most widely treated diseases were heart and cancer (Newswire, 2015).

Research conducted by Fatt and AbdulRahim (2014) shows that from 2007-2012 Malaysia has been a health tourism destination for tourists around the world. According to MHTC, the total number of tourists doing health care has increased by $49.2 \%$. Malaysia also received a positive response from patients who went to Malaysia to get the health service. (Chan-fatt, 2014)

Studies conducted by Malaysian researchers state that Malaysia has low medical costs and modern infrastructure facilities compared to other countries, especially with countries in Asia that also develop this medical tourism, such as India, Singapore, Thailand, even the Philippines (Azmi \& Chandran, 2018). According to the Malaysia Healthcare Travel Council (MHTC 2017), Malaysia stands out as a medical tourism destination compared to other countries mainly because it is facilitated and monitored by the Ministry of Health. Even Mujani (2012) said low medical costs and modern infrastructure facilities are all under the competitive element of tourism destinations, which attract tourists to visit Malaysia for treatment and health services.

Malaysia has branded itself as it is often written in its country's tagline as 'Truly Asia' this certainly shows that Malaysia claims to represent the Asian continent, although there is no evidence to suggest any resemblance to other countries in Asia such as Thailand or the Philippines (Che-Ha et al., 2016)

Is it also affecting the Indonesian people in assessing Malaysia as a destination country 
for treatment and tourist destinations? So, the research question is how the opinion of the Indonesian people on the medical tourism industry developed by Malaysia.

This research is developed from various concepts, namely medical tourism and public opinion. Medical tourism is a phenomenon that has developed since the era of globalization. Globalization itself is an era that allows for the obscurity of a country's borders. The phenomenon of people exploring other countries for various purposes occurred at that time, and tourism became one of the most common destinations one uses as an excuse. In all cases, tourism is used in the context of travel for economic activities either to utilize services or to utilize products produced by a country. At the same time, tourism is used for travel activities that provide services and products. In both cases for medical tourism, it can be said that what is achieved by these tourists is the health and well-being of individuals from those who use health services and who consume the products produced by the country.

The phenomenon of health search involves tourism because it requires displacement from one's environment, which in many cases means crossing national borders. Outside of the local environment of the individual, he or she is experiencing not only changes in the physical environment but also jurisdiction, as it concerns access to healthcare. They will remain at their destination for a limited time. In terms of available goods and services, the spectrum ranges from drugs related to complementary medicine to conventional medicine preparations, and alternative medicine is also therapeutic to diagnostic and invasive procedures. In this case, it turns out that there are differences in the concept of health and medical tourism, as revealed by Carrera and Bridges (2006). According to them, there are three crucial factors used to identify health tourism, namely geographical regulation, consumption of healthrelated interventions, and structural facilities where health interventions are available.

While medical tourism can be understood as part of health tourism formed by meeting all three factors (intervention, structure, and setting). Carrera and Bridges define health tourism as organized travel outside one's local environment to maintain, improve, or recover one's health. In contrast, medical tourism is organized travel outside one's health jurisdiction to improve or recover one's health through medical intervention. Comparing health tourism and medical tourism, then referral points are seen from the destination and limited by the health system. This limitation considers the territorial principle governing the health care system, where access to health care is limited to the boundaries of the country normally but not necessarily by the country's territorial boundaries (Carrera \& Bridges, 2006).

Medical tourism is a tourism service industry that has not long appeared when compared to other tourism industries. Medical tourism is defined as an activity in which an individual intends to obtain medical treatment either by traveling domestically or abroad. Medical tourism itself develops along with the development of the need for health and tourism, so it can be interpreted as medical tourism as an economic activity that involves trade in services and involves two sectors: medicine and tourism. (Bookman \& Bookman, 2007). It is assumed that everyone comes from everywhere, 'shopping' to find a doctor in the international healthcare market and, as a result, enjoy cost savings as an alternative to home care. In addition, travelers who buy health care usually get a package of deals that includes their care plus air transportation, transfers, accommodation, and post-care vacations. Just as chi kin yim conveyed in the results of his research that took the theme of healthcare destinations in Asia: as part of a health care package, customers receive bonus vacations and sightseeing in foreign countries and exotic cultures (Bookman \& Bookman, 2007).

The Medical Tourism Association (2017) defines medical tourism as the process of traveling outside the country of residence to get medical treatment. According to LubowieckiVikuk (2011), medical tourism is defined as "conscious activity, in which a medical traveler intends to obtain health services, either in his home country or in a foreign country to maintain (or acquire) a better health condition, and/or the aesthetic appearance of his own body, combined with relaxation, regeneration of physical and mental strength, sightseeing and entertainment." Lunt, et al. (2011) explain that medical tourism as "individuals are selected to travel through international borders to receive any type of medical treatment that may have 
any type of medical service, e.g., dental care. However, to set limits on what is meant by health and be taken into account as medical tourism for a trade is not easy. Within the scope of this medical treatment, not all will be included in the health trade. Cosmetic surgery, for example, is an artistic reason rather than a reconstructive reason; therefore, it must be believed outside the scope of health." Tilman et al. (2008) define medical tourism as "an individual, whose goal in migrating to a foreign country is to obtain medical care, excluding emergency tourists, health tourists, expatriates (someone living outside his or her home country), a patient traveling to a neighboring area to the nearest available treatment." (Chandran \& Azmi, 2018).

According to the World Health Organization (WHO), medical tourism is a growing trend with enormous economic implications. A report from Organization for Economic Cooperation and Development (OECD) noted that healthcare trade provides competitive opportunities for developing countries in this arena, given the abundance of manpower and the availability of capital and skills in medicine. United Nations Conference on Trade and Development (UNCTAD) monitors trade between countries, noting for the first time that trade in services, including healthcare, can benefit developing countries. Furthermore, now that countries in the Asian continent, India, and Malaysia have started to join Thailand and Singapore, which are already well established in medical tourism, the Philippines is not far behind. More and more of these countries have the necessary manpower, investment capital, knowledge, and motivation to supply medical tourism facilities.

Abdulrahman Alili (2016) 40\% of patients traveling abroad to seek medical care are due to advanced technology in the host country. Meanwhile, $32 \%$ of them sought better medical care, $15 \%$ due to more extended waiting periods, and $9 \%$ of travelers traveled abroad due to low medical costs. Everyone travels to another country for a different purpose, and most of those destinations are not available in their respective countries. (Azmi \& Chandran, 2018).

In general, there are three types of medical tourism known as domestic medical tourism, cross-border medical tourism, and diaspora medical travel. Domestic medical tourism is also called local medical tourism when an individual travels from one state to his or her home country for medical treatment. Crossborder medical tourism is notoriously used in the European Union, where workers, migrants, and retirees will travel from one European country to another for medical treatment. It requires individuals to travel long distances from their neighboring countries. Diaspora medical travel is where medical travel agencies have established specialized medical travel programs for individuals associated with cultural ties or family roots in medical purposes. (Munro, 2012).

People travel to get treatments that are not available locally or spend less than they do at home. The increased supply of medical tourism is directly related to the liberalization of service trade, increased cooperation between the private and public sectors, the easy dissemination of global information about products and services, and most importantly, the success of tourism and the health sector. (Bookman \& Bookman, 2007).

To make medical tourism known to foreign tourists, then a promotional strategy is needed that tries to show some of the advantages of medical tourism in the country, namely: Competitive Prices (Competitive Prices). Some developing countries can offer medical tourism services at competitive prices for micro and macro reasons. The quality of medical services around the world has become similar, and service prices are the main differentiator. What explains the price difference among medical tourism providers in developing countries? According to The and $\mathrm{Chu}$, the difference in cost determines the price difference. Among other things, the cost of input of physical capital and skilled labor is of the utmost importance, especially in invasive medical tourism and diagnostics. The benefits of reducing production costs are clear. For international patients, low production costs translate into savings that can be passed on to consumers in the form of lower prices. International patients also benefit in connection with the attention they receive.

Human Capital. Virtual media coupled with global internet and air delivery capabilities will create a new and challenging competitive environment for countries, companies, and individuals. Education and skills are determinants of productivity because marginal machine products are higher when used with 
highly skilled human resources. For medical tourism, countries that have more human resources, especially human resources suitable for the medical tourism industry, benefit more than countries that do not. To supply medical tourist services, then the country needs the right quality of labor and adequate numbers. Providing qualified human resources requires resources that can develop brainpower. Education, skills, and training, all of which are contained in the definition of human capital, are relevant to the extent that they determine the extent to which a worker can adapt to new conditions, be willing to think creatively, take risks, follow instructions, and respond to incentives. For example, the unique skills demanded by the economic world will change along with changes in economic demands. At first, the need for lowskilled workers increases in the early stages of industrialization, the demand for high-skilled workers is even stronger today. Moreover, for medical tourism, the resources needed are those who have the ability of medical and business skills that are very special. In medical tourism also requires good language skills. Fluency in the world's languages, primarily where medicine and biomedical research are being conducted, is a clear advantage for countries pursuing medical tourism.

Domestic Research and Development. Technological change is inevitable, encompassing new, better, and cost-effective ways to produce old products, as well as producing entirely new products. Sometimes technological changes result in higher outputs using the same number of inputs. Likewise, in medical tourism, the perpetrators are required to always have novelty in producing health products and providing health services. Given the highly technical aspects of medical tourism, especially those related to invasive procedures and diagnostic services, being a source of technological innovation is very important. Innovations in health technology used for medical tourism have become one of the benchmarks of the country's competitive ability in medical tourism.

Developed Physical Infrastructure. Infrastructure is defined as the amount of physical and financial capital contained in roads, railways, waterways, airways, as well as other forms of transportation and communication, plus water supplies, financial institutions, electricity, and public services, such as health and education. Countries with welldeveloped infrastructure are better positioned to provide medical tourism and facilitate the provision of related services. To the extent that developed infrastructure facilitates and integrates all economic activities because medical tourism depends on the quality and quantity of infrastructure to determine the speed and diversity of service industry development. Infrastructure improvements contribute to the tourism industry and, at the same time, serve the local population and improve living standards. When infrastructure is inadequate and inadequate, the transportation system prevents the flow of goods serving the medical and tourism industries; financial institutions cannot provide capital for investment in clinics, hospitals, accommodations, restaurants, car rental agencies, and shops; Communication cannot encourage the relationship to the home that patients and travelers often request. Such conditions hindered the development of the medical tourism industry and ultimately detailed aspirations for national economic growth.

Developed Political and Legal Institution. A country with a peaceful political system, characterized by the existence of developed and respected legal institutions and where the authorities manage to maintain law and order, has an advantage in providing medical tourism. Tourists will be drawn to an area without the risk of a coup, revolution, or uprising. They want certainty that the rule of law exists and that law and order can provide a safe environment for their medical services.

Market Economics. The capitalist economy is referred to as the market economy because of the enormous role of the market in the pricing and allocation of resources. The market economy is also characterized by competition, private ownership, and participation in the global economy. Countries whose economies are based on markets have advantages over countries with minimal market roles in promoting medical tourism. Market economies are flexible, respond more quickly to stimuli, and are more likely to generate economic growth. The government in the market economy will provide a conducive environment for the growth and development of medical tourism through liberalization policies that further introduce dynamics in the economic environment. 
The Confluence of High-Tech Medicine and Traditional Healing. When a country can combine high technology and traditional medicine, it appeals to a broader market segment. Western suppliers respond to the increasing demand for combination holidays and healthcare by providing vacations built around traditional healthcare providers. To gain greater market share, the public and private sectors in developing countries promote traditional healing side by side with high-tech medicines.

Tourist Appeal. For medical travelers who want a tour of medicine or want to be entertained by their friends or family while undergoing medical procedures, less developed country (LDC)destinations with attractive tourist attractions will be in high demand. All countries have abundant natural beauty and cultural appeal, all of which provide a pleasant setting for restoring and experiencing something new. Later, medical tourists will return home to rest. Eventually, medical travelers will spread the word, encouraging others to follow their path, or they may just brag about their experiences (Bookman \& Bookman, 2007).

Public opinion, according to Bernays, is the aggregate opinion of individuals from the people who make up society or community groups. To understand public opinion, researchers must study individuals who dominate the form of groups. (Crystallizing Public Opinion by Edward Bernays (z-Lib.Org). Epub, n.d.). Public opinion in this phenomenon of the medical tourism industry is an early concept of a brand country that shows that foreign policy is not only about interacting with others but also includes the values of communication and identity narrative to citizens. (Browning, 2015). Positive public opinion is at least expected to illustrate the country's reputation in the eyes of foreign nationals because national reputation is all about having a good name in the world of the nation. According to Mercer (1996), national reputation is Illustrated from the collective judgment of a foreign country's image and character that are then used to predict or explain its future behavior (Wang, 2006).

\section{RESEARCH METHODS}

The research method used in this study is descriptive survey research, which uses questionnaires as research instruments and tries to measure Indonesian opinion on Malaysian medical tourism. Singarimbun and Effendi (1991) say that descriptive research aims to develop concepts and gather facts found in research. The study sought to find simple patterns based on specific concepts. (Bajari, 2015).

In this study, researchers used questionnaires developed from the concept of tourism communication in the medical tourism industry for developing countries and asked 96 respondents spread across Sumatra and Java. The research was conducted in 2020.

The analysis is done by describing one by one the findings of the development of the data obtained because, according to Vredenbregt (1978), descriptive research must elaborate in detail about a collectivity where the representation must be guaranteed. (Bajari, 2015).

\section{RESULTS AND DISCUSSION}

This study found that the Indonesian people assess measurable Malaysian medical tourism from the credibility of hospitals that can provide complete specialists for all kinds of diseases, equipment for examination and sophisticated care, the ability to convey information to patients and patients accurately, able to provide professional health services, and able to provide concise administrative services. The opinions formed are as follows.

The data shown in table 1 and table 2 is data that tries to measure how respondents approve of hospital services in Malaysia. What is meant by its services in this study is more directed at Malaysian hospitals' functions in dealing with patients from outside Malaysia. As revealed by the Malaysia Healthcare Travel Council (MHTC) at the beginning of this study, Malaysia is trying to build an industry in medical services specifically aimed at foreign nationals. One way is to establish that only private hospitals can handle patients who are not Malaysian citizens. In fact, many Indonesian citizens do not see the private hospital but emphasize information obtained from people who have been treated in Malaysia before; this is revealed in interview data with previous informants. Nevertheless, 
Table 1 Indonesian Public Opinion on the Use of Advanced Medical Equipment

Hospitals in Malaysia use sophisticated medical tools to check their patients

\begin{tabular}{ccc}
\hline Answer & f & $\%$ \\
\hline Strongly Agree & 48 & 50,0 \\
Agree & 44 & 45,8 \\
Neutral & 4 & 4,2 \\
Total & 96 & 100,0 \\
\hline
\end{tabular}

Source: Research results, 2020

the results showed positives, statements, or statements built in this study did not lead widely to all health services in Malaysia (such as clinics or other medical establishments). However, still directed at hospitals in Malaysia, such as information submitted by MHTC, the power revealed almost $100 \%$ expressed positive things about how hospitals in Malaysia play their function as a hospital. Sick people who serve patients from outside the country. A total of $95.9 \%$ of respondents expressed their agreement that hospitals in Malaysia provide specialist doctors for all kinds of diseases, this is positively indicated when compared to data that in Indonesia, there is a lack of evenly distributed specialist doctors, especially for the Sumatra region so that many Indonesian citizens are looking for specialists to neighboring countries. $95.8 \%$ of respondents also agreed that hospitals in Malaysia are preparing sophisticated equipment to handle patients, especially foreign patients visiting their hospitals. In line with qualitative data submitted earlier, those hospitals use advanced medical tools to examine and even treat foreign patients. $92.7 \%$ of respondents also agreed in terms of accurate and appropriate delivery of information to patients and families. The trust of the patient and the patient's family, in this case, is very awakened from the information provided. This statement shows that respondents trust more information submitted by hospitals in Malaysia. Diagnosis and explanation of the patient's condition are believed to be confirmed by respondents so that for respondents, this information is considered accurate. $92.7 \%$ of respondents stated that hospitals in Malaysia provide professional services. From this statement, researchers see
Table 2 Indonesian Public Opinion on Rapid Administrative Services

The administrative service process carried out by the hospital is not convoluted

\begin{tabular}{ccc}
\hline Answer & f & $\%$ \\
\hline Strongly Agree & 49 & 51,0 \\
Agree & 40 & 41,7 \\
Neutral & 7 & 7,3 \\
Total & 96 & 100,0 \\
\hline
\end{tabular}

Source: Research results, 2020

that respondents are very satisfied with the services provided by hospitals in Malaysia. The professionalism is shown by a variety of services not only that include health services, but also other things such as hospitality and ease of access to the desired information. As well as professionalism in service, $92.7 \%$ of respondents also felt administrative services that were not convoluted. Respondents agreed that their experience in doing treatment in Malaysia was not burdened with administrative matters such as the requirements of being a patient, referral letters, and so on; this led to comfort in carrying out treatment.

The second thing that concerns the Indonesian people is the integrity of Malaysia in developing the industry. Integrity is more about rulemaking and government policies that are considered to be very beneficial for tourists and patients visiting Malaysia.

Tables 3 (three) to 5 (five) are data that try to reveal how respondents give opinions on the integrity built by the Kingdom of Malaysia through established rules and policies. In an interview at the beginning of the MHTC research as a representative of the Kingdom of Malaysia in terms of medical tourism developed by neighboring countries stated that the Government of Malaysia, through the Ministry of Finance (initially the Ministry of Tourism), set several standards that must be followed by private hospitals that are members of the MHTC. The latest data revealed by MHTC that there are 73 private hospitals under the auspices of MHTC from 200 private hospitals in Malaysia. According to Suhaimi (2019), in his interview, the Malaysian Government decided on hospital qualification standards that covered 
Table 3 Indonesian Public Opinion on Hospital Doctor Standards

The specialist doctors who treat patients are mostly domestic graduate doctors (Malaysia)

\begin{tabular}{|c|c|c|}
\hline Answer & & $\%$ \\
\hline Disagree & 16 & 16,7 \\
\hline Neutral & 45 & 46,9 \\
\hline Agree & 32 & 33,3 \\
\hline Strongly Agree & 3 & 3,1 \\
\hline Total & 96 & 100,0 \\
\hline
\end{tabular}

Source: Research results, 2020

Table 5 Indonesian public opinion on the rules set by the Government of Malaysia

The Government of the Kingdom of

Malaysia provides supervision and rules for every hospital in Malaysia to follow

\begin{tabular}{ccc}
\hline Answer & $\mathrm{f}$ & \\
& 24 & 25,0 \\
Strongly Agree & 54 & 56,3 \\
Agree & 18 & 18,8 \\
Neutral & 96 & 100,0 \\
Total &
\end{tabular}

Source: Research results, 2020

the competence of doctors, services up to the price or cost offered to foreign patients. For researchers, the provision of this qualification standard is a normative dimension that patients or families of patients then interpret from Indonesia to build a positive image of this medical tourism. According to Kamus Besar Bahasa Indonesia (KBBI), normative has the means as an effort to stick to the rules or norms that apply, in this case, the norms set by the Malaysian government for private hospitals serving foreign patients. From some of the established norms dug back through informants, trying to see how informants see this rule as a standard of hospital services in Malaysia, the results obtained that the image attached to informants related to this standard is the standard of health services, the standard of doctors who according to MHTC must be specialists who not only come from Malaysian graduates but also
Table 4 Indonesian Public Opinion on The Standard of Medical Devices Used

Medical devices used in treating and treating patient nurses are the latest output tools

\begin{tabular}{ccc}
\hline Answer & f & $\%$ \\
\hline Strongly Agree & 16 & 51,0 \\
Agree & 49 & 41,7 \\
Neutral & 29 & 7,3 \\
Disagree & 2 & 2,1 \\
Total & 96 & 100,0 \\
\hline
\end{tabular}

Source: Research results, 2020

overseas graduates such as Australia, Europe, China, even India. In addition to more selling, professional services are also expected to serve patients from various countries. In addition, medical devices are used that are visible during the treatment period and felt until receiving the diagnosis and treatment results. The statement that every hospital in Malaysia has Standard Operational Procedures (SOPs) listed in every hospital responded positively, proving that $85.4 \%$ expressed their agreement. That means respondents recognize that SOPs are one of the essential points that impress them on hospital services in Malaysia. Statements regarding doctor standards are deliberately made negative to measure better how they understand the specialist doctors who handle them, as many as $63.8 \%$ expressed their doubts that the specialist doctors are Graduates of Malaysia, most have confidence that these doctors are graduates abroad, in line with qualitative data obtained in previous data that expressed confidence that the doctors who treated them were graduates abroad, Seen from the data provided by the hospital, or information submitted by relatives or friends who have been handled by the doctor before, but even though 36.7 percent expressed their approval that the doctor who treated them was a Malaysian domestic doctor, this data also shows that Indonesians tend to be difficult to distinguish the term doctor domestically and abroad because for Indonesians, Domestically is Indonesia, and abroad is outside Indonesia. For the medical device standard, $67.7 \%$ agreed that the devices were indeed the latest output, although $30.2 \%$ expressed doubts. If you look at the results of interviews with informants before, 
Table 6 Indonesian people's opinion on cities in Malaysia

Cities in Malaysia are modern cities, with pleasant streets, tall buildings, and plenty of places to buy souvenirs

\begin{tabular}{|c|c|c|}
\hline Answer & $f$ & $\%$ \\
\hline Strongly Agree & 22 & 22,9 \\
\hline Agree & 57 & 59,4 \\
\hline Neutral & 9 & 9,4 \\
\hline Disagree & 8 & 8,3 \\
\hline Total & 96 & 100,0 \\
\hline
\end{tabular}

Source: Research results, 2020

doubts can indeed be revealed because of the ignorance of patients or their families in the equipment used. There are several causes, but the most prominent is because when patients start to be treated by the hospital, the patient's family is asked to wait and is not allowed to wait indoors and even stay in the hospital as in Indonesia. Patients who will be treated are directly served by the hospital so that the family 'knows the right thing' with small things such as preparation to enter the room and so on. The family is usually asked to wait at the hotel or guesthouse provided by the hospital. After the treatment, the family was informed of the next steps. Visible medical devices are usually in the examination clinic or the treatment room. Nevertheless, although these standards are not fully known to the Indonesian people as users of Malaysian medical services, $81.3 \%$ of respondents believe that the Kingdom of Malaysia sets stringent rules, which are also believed to be followed by hospitals. There is not a single respondent who disagrees with the statement, so it can be believed that respondents have a good image of the Malaysian government as a country that also guarantees the comfort of foreign nationals who seek treatment in their country.

As befits tourism, Indonesian people also have their own opinion about the beauty of tourist destinations offered by Malaysia, simply because culturally and similar natural conditions, Indonesian people prefer the beauty of Malaysia seen from the point of view of the modernity of a city, and able to display contemporary tourism.
The last table 6 is a table that tries to present data on how tourist destinations as part of Malaysian medical tourism are detected by Indonesian citizens. The data shown here emphasizes more on the beauty that Malaysia is trying to present in its tourist areas. As is well known, Malaysia also has an international tourism program called Malaysia Truly Asia that tries to show the diversity that exists in Malaysia as a country's strength. Malaysia has a variety of tourist destinations, from culinary tourism, culture to contemporary tourism. For medical tourism, this tourist destination becomes something that cannot be separated from the destination of citizens outside Malaysia in visiting the country. Medical tourism itself intends to invite foreign nationals to enjoy the country in addition to treatment also by traveling. MHTC offers many tourist destinations in its social media accounts, and even travel-travel agents in Indonesia also offer the same thing. Like a complete package between treatment and tourism, it was developed to become an industry in itself. MHTC recognizes that with the development of medical services, directly also grow other things such as hospitality, souvenirs, labor, taxis, etc. However, the efforts made by the Malaysian government is offering this complete package of interview data do not show significance, because most informants state that when treatment is different from when traveling, although the things that impress the source of this country more on modern things contained in the region they have visited, Places to buy souvenirs and contemporary tourism developed by Malaysia, for tourist destinations in the form of relics are not too much of a concern although still measured in this study. A total of $82.3 \%$ of respondents expressed their agreement with the country's modernity. Good streets, tall buildings, bridges, other infrastructure become a measure of Malaysian modernity in the minds of Indonesians. The results of previous interviews even expressed admiration for the trains developed in the country. Mass Rapid Transit (MRT) and Light Rapid Transit (LRT) developed in Malaysia are also in high demand by Indonesian citizens who visit there and the obligation to arrive at the Twin Tower, as evidence has reached Kuala Lumpur. The number of places to buy souvenirs is also a target for tourists from Indonesia. In addition to the city's modernity, Malaysia is also famous for 
relics in the colonial era, both Portuguese and British. Just like Indonesia has been colonized by other nations and left some relics such as fortifications or cannons, Malaysia makes these relics one of the underdog tourist destinations. In interviews with informants that have been presented in the previous chapter, many of the informants stated that historical tourism in Malaysia does not attract tourists because informants prefer contemporary tourism or modern tourist destinations. For contemporary tourism that seems to be an obligation for every country in inviting tourists to visit his country, respondents who expressed their approval amounted to $71.8 \%$. They agree that Malaysia is also developing contemporary tourism, which is more Instagrammable, although it may develop from the natural beauty that already existed before. From these data, it can be ascertained that respondents have a favorable opinion and impression on the development of tourism in Malaysia.

\section{CONCLUSION}

The results showed that more than $60 \%$ of Indonesians gave a favorable opinion of the medical tourism industry developed by Malaysia. Malaysia, which began to build this industry from 1998 to today, has managed to provide a positive experience that makes Indonesians have a deep impression on the services and treatments that have been obtained during treatment to the country. Without experience, there is no way an opinion will be formed.

Positive experiences that have been obtained by Indonesian people either through the experience of direct contact or getting information from the media become the basis of the formation of these opinions, and this opinion is the basis for spreading more information to others, who may want to travel the same, or who have done at different times.

This experience then reduces and adds several categories of how the medical tourism industry is when viewed from the view of the Indonesian people. The findings are that not all categories of the medical tourism industry in developing countries are the same in all countries, proven Indonesians see price as not one that is their reference in carrying out treatment. In addition, the Indonesian people are not so concerned with the research results that Malaysian doctors may have done because those who feel more felt are the service. The ability to unite high technology with traditional is not an advantage because Indonesians see Malaysia as a country with technology in medicine that is better than Indonesia.

Advice for further research, from the results of these findings, can be examined how word of mouth communication occurs from this phenomenon because the opinion that has been conveyed is a representation of the impression formed, and the impression is a result of the process of experience that will eventually be conveyed again through stories delivered by word of mouth, and as the concept of marketing, promotion through word of mouth. It is the most effective promotion when compared to any marketing tool.

\section{REFERENCES}

Azmi, N. A., \& Chandran, S. D. S. (2018). Medical Tourism industry in Malaysia in the 21st Century. February.

Bajari, A. (2015). Metode penelitian komunikasi (pertama). Simbiosa Rekatama Media.

Bookman, M. Z., \& Bookman, K. R. (2007). Medical tourism in developing countries. Palgrave Macmillan.

Browning, C. S. (2015). Nation branding, national self-esteem, and the constitution of subjectivity in late modernity. Foreign Policy Analysis, 11(2), 195-214. https:// doi.org/10.1111/fpa.12028

Carrera, P. M., \& Bridges, J. F. P. (2006). Globalization and healthcare: understanding health and medical tourism. 447-454.

Chandran, S. D., \& Azmi, N. A. (2018). Key drivers of medical tourism in Malaysia. $10(1), 15-26$.

Chan-fatt, C. (2014). Tourism, health, and income in Malaysia. 39, 2-7.

Che-Ha, N., Nguyen, B., Yahya, W. K., Melewar, T. C., \& Chen, Y. P. (2016). Country branding emerging from citizens' emotions and the perceptions of competitive advantage: The case of Malaysia. Journal of Vacation Marketing, 22(1), 13-28. https:// 
doi.org/10.1177/1356766715586454

Crystallizing Public Opinion by Edward Bernays (z-lib.org).epub. (n.d.).

Mulyana, D., Rahmawati, D., Gidion, H., \& Roselina, E. (2021). Unraveling communication between child patients' family members and healthcare staff. Jurnal Kajian Komunikasi, 9(1), 1-11.

Munro, J. W. (2012). What is Medical Tourism? MTQUA.

Newswire. (2015). MHTC: 500.000 Orang Indonesia berobat ke Malaysia pada 2015. Bisnis.Com. https://ekonomi.bisnis. $\mathrm{com} / \mathrm{read} / 20160507 / 103 / 545041 / \mathrm{mhtc}-$ 500.000-orang-indonesia-berobat-kemalaysia-pada-2015

Ormond, M., Mun, W. K., \& Khoon, C.C.(2015). Medical tourism in Malaysia: How can we better identify and manage its advantages and disadvantages? Global Health Action, 8(1). https://doi.org/10.3402/gha.v7.25201

Putri, N. E., Hakim, N., \& Yamin, M. (2016). Ecological footprint and biocapacity analysis for flooding prevention in south Sumatera. Jurnal Mimbar, 32(1), 58-64.

Tourism Malaysia. (2020). Malaysia.Travel.

Wang, J. (2006). Managing national reputation and international relations in the global era: Public diplomacy revisited. Public Relations Review, 32(2), 91-96. https://doi. org/10.1016/j.pubrev.2005.12.001

Yasir. (2021). Komunikasi pariwisata dalam pengembangan destinasi wisata di Kecamatan Kuok Kabupaten Kampar. Jurnal Kajian Komunikasi, 9(1), 108-120. 